DOI: https://doi.org/10.32353/khrife.2.2020.42

УДК 339.137.2:347.77

\title{
I. I. Бордакова,
}

головний судовий експерт відділу товарознавчих, гемологічних, економічних, будівельних, земельних досліджень та оціночної діяльності

Сумського наукового-дослідного експертно-криміналістичного центру

Міністерства внутрішніх справ України, м. Суми, Україна,

ORCID: https://orcid.org/0000-0003-0997-2685, e-mail: bordachok.2011@ukr.net

\section{ВИКОРИСТАННЯ ТОВАРНИХ ЗНАКІВ (ТОРГОВИХ МАРОК) ТА ÏХ ЗНАЧЕННЯ}

У статті висвітлено питання значення товарних знаків, їх створення та використання. Розглянуто особливості маркування $i$ значення типовоі термінології, а також досліджено процедуру ідентифікації товару з урахуванням маркувальних позначень. Ефективна система маркування сприяє захисту споживачів від недобросовісної торгівлі та конкуренції. Товарні знаки (торгові марки) потрібні також державним органам, щя відповідають за перевірку якості товарів і послуг і допомагають розпізнати товари й послуги, які не відповідають вимогам закону або які виявлено в результаті скарг чи лабораторних перевірок. Акцентовано увагу на питаннях правового регулювання, користування та розпорядження товарними знаками.

Ключові слова: маркування, товарний знак, торгова марка, торговельне найменування, фірмовий стиль, бренд, ідентифікація, підробка, копія, якість, право власності, інтелектуальна власність.

Постановка наукової проблеми. Невід'ємним елементом ідентифікації товарів і послуг $є$ маркування. Наявність елементів маркування індивідуалізує товари та послуги. Маркування продукції можна розглядати як перший захід для спрощення доведення товарів від виробника до споживача. Для того щоб споживачеві було легко відрізнити товар конкретного виробника від безлічі товарів і послуг інших виробників, товар повинен мати ознаки індивідуальності, які відображаються у його маркуванні. Головним призначенням маркування $є$ доведення основних відомостей про товар до споживачів, а також ідентифікація товару.

Аналіз основних досліджень i публікацій. Питання створення та призначення маркувальних позначень, а також процеси формування індивідуальності торгових марок як брендів докладно відображено у працях С. С. Гаркавенко ${ }^{1}$, М. І. Дідківського ${ }^{2}$, В. Я. Кардаша ${ }^{3}$,

${ }^{1}$ Гаркавенко С. С. Маркетинг: підручник. Київ, 2002. 712 с.

2 Дідківський М. І. Зовнішньоекономічна діяльність підприємства: навч. посіб. Київ, 2006. 462 с.

${ }^{3}$ Кардаш В. Я. Маркетингова товарна політика: навч.-метод. посіб. для самост. вивч. дисцип. Київ, 2000. 124 с.

(C) I. I. Бордакова, 2020 
В. Д. Малигіної, Л. Д. Титаренко ${ }^{1}$. На прикладі діючих торгових підприємств автори С. М. Ілляшенко ${ }^{2}$, І. Я. Рожков і В. Г. Кисмерешкін ${ }^{3}$ роз'яснили основні різновиди й особливості товарних знаків, власного імені, стилю тощо. Крім того, проаналізовано процедуру ідентифікації з урахуванням методів і засобів, які впливають на кінцевий результат ${ }^{4}$.

Досліджено процедуру узаконення права власності на знаки для товарів і послуг, яку здійснюють з посиланням на законодавчу базу, а саме на Закон України «Про охорону прав на знаки для товарів і послуг» (далі - Закон про ОПЗТП) ${ }^{5}$ та Кримінальний кодекс України (далі - KК України) ${ }^{6}$.

Мета статті - у процесі дослідження споживчого ринку висвітлити питання значення маркування для ідентифікації товарної продукції та іiі оригінальності, виявити розбіжності між оригінальною продукцією, копією і підробкою, а також визначити порядок правової охорони товарного знака, яка надається на підставі його державної реєстрації; з'ясувати винятковість права власника товарного знака користуватися й розпоряджатися цим товарним знаком, а також забороняти його використання іншим особам.

Викладення основного матеріалу дослідження. Маркування товару має особливе значення під час посилання на online-торгівлю (інтернет) та в разі реалізації продукції в місцях самообслуговування, точніше - під час продажу товарів за допомогою автоматів. Проте, для звичайної торгівлі маркування також має неабияке значення, суттєво зменшуючи необхідність і наявність особистих консультацій та інформування про виробника і його популярність на споживчому ринку. На жаль, нагальним проблемним питанням є збільшення на споживчому ринку кількості неякісної продукції, яка належить до категорії підробок, під іменем відомих торгових марок.

У процесі планування продукції важливим елементом для виробника $€$ визначення товарної марки - імені, знака або символу (чи їх поєднання), за допомогою яких ідентифікують продукцію та послуги виробників і посередників.

Варто зазначити, що маркування продукції має кілька значень для виробника:

${ }^{1}$ Малигіна В. Д., Титаренко Л. Д. Основи експертизи продовольчих товарів: навч. посіб. для студент. внз. Київ, 2009. 296 с.

${ }^{2}$ Ілляшенко С. М. Маркетингова товарна політика: підручник. 2005. 234 с.

${ }^{3}$ Рожков И. Я., Кисмерешкин В. Г. Брендинг: учеб. для бакалавр. Москва, 2019. $331 \mathrm{c}$.

${ }^{4}$ Малигіна В. Д., Титаренко Л. Д. Зазнач. твір.

${ }_{5}^{5}$ Про охорону прав на знаки для товарів і послуг: Закон України від 15.12.1993 p. № 3689-XII (зі змін. та допов.). URL: https://zakon.rada.gov.ua/laws/show/3689-12 (дата звернення: 04.06.2020).

${ }^{6}$ Кримінальний кодекс України: Закон України від 05.04.2001 р. № 2341-III (зі змін. та допов.). URL: https://zakon.rada.gov.ua/laws/show/2341-14 (дата звернення: 04.06.2020). 
- налагодження прямих зв'язків зі споживачами, що дає змогу уникнути проміжних ланок у каналах збуту;

- широке повідомлення про відмінності товару від подібних до нього (для того, щоб забезпечити інтенсивний вплив на певний ринковий сегмент та найбільш сприятливі умови для здійснення ефективної цінової політики, яка грунтується на довірі до марки);

- акцентування на тотожності схожих товарів за визначеними критеріями (якість, цінова лінія);

- символічне посилання на споживчі властивості та корисність виробів для покупців;

- захист від підробок і недобросовісного використання зовнішньої схожості.

Важливе значення маркування продуктів має також для споживачів.

По-перше, маркування допомагає впізнати чи відрізнити товар, з яким пов'язано позитивний або негативний досвід. Це дає змогу споживачеві придбати товар з мінімальними зусиллями та 3 мінімальними витратами часу.

По-друге, воно сприяє розпізнаванню особливо престижних продуктів.

По-третє, відома марка є додатковою гарантією якості, що дуже важливо для покупців, яким бракує професійних знань для кваліфікованого оцінювання технічно складного товару ${ }^{1}$.

У рекламно-комунікаційній практиці існує багато термінів, які конкретизують товарні знаки.

Часто в побуті термін товарний знак замінюють такими поняттями, як торгова марка, логотип, фірмова емблема, фірмовий знак, бренд та ін.

Товарні знаки бувають словесними, звуковими, комбінованими, тривимірними та ін. Крім того, можна використовувати ініціали, цифри, міфологічні образи, власні імена, географічні назви, іноземні слова, сполучення слів тощо.

Головним елементом маркування є товарний знак, який відрізняється особливостями ідентифікації, оригінальністю й може бути зареєстрованим. Зареєстрований товарний знак є об'єктом інтелектуальної власності й охороняється законодавством.

Отже, розглянемо типові терміни та їхні значення.

Торгова марка - абревіатура, слово, символ, цифра (наприклад, «Растішка», стилізоване зображення сузір'я Плеяд в автомобілів Subaru, марка мережі аптек «36,6» та ін.). Ідентифікаційні функції марки можуть виконувати слогани («Мир твоєї волі — МТС!»), звуки («Ш-Ш-ш-ш» — у напоїв Schweppes), джингли (позивні, характерні мелодіï), особлива форма виробів (класична пляшка Coca-Cola), персонажі (кіт Матроскін у кисломолочних виробів «Простоквашино») та ін.

\footnotetext{
${ }^{1}$ Кардаш В. Я. Зазнач. твір.
} 
Торговельне найменування - це знак, під яким компанія здійснює комерційну діяльність. Інколи воно збігається з торговою маркою (Sony, Siemens, Philips) ${ }^{1}$.

Розглянемо деякі приклади ідентифікації різних товарних марок, які використовують фірмові товарні знаки:

- $\quad$ фірмове ім'я - літера, слово, набір літер чи слів (наприклад, Сумське $A T$ «CEЛMI», утворене на основі абревіатури Сумського заводу електронних мікроскопів);

- $\quad$ фірмовий знак - символ, малюнок, відмітний колір або інше позначення (наприклад, фірмовий знак Лебединського заводу поршневих кілець - це вписаний у коло силует лебедя);

- торговий образ - персоніфікована торгова марка (наприклад, модельного одягу «Михайло Воронін»);

- торговий знак - фірмове ім'я, фірмовий знак, товарний образ чи їх поєднання, офіційно зареєстровані в Міжнародному реєстрі й захищені юридично (наприклад, модельного одягу й аксесуарів Tот Klaim, трилисник автомобіля Mitsubishi тощо) ${ }^{2}$.

Отже, товарний знак $є$ важливим елементом такого узагальненого поняття, як фірмовий стиль, тобто сукупність засобів (кольорів, слів і словосполучень, графічних зображень і друку), які забезпечують негайне впізнавання покупцями й виокремлення цих товарів 3-поміж значного розмаїття подібних товарів-конкурентів.

Фірмовий стиль, крім товарного знака, передбачає ще й власний логотип (оригінальне зображення повної або часткової назви фірми), фірмовий колір (сполучення кольорів), фірмовий комплект шрифтів, а також фірмові константи (формат друку, систему друкарського набору тексту й виконання ілюстрацій) ${ }^{3}$.

Крім того, існує таке поняття, як бренд,-— це образне поєднання самого товару або послуги $з$ добіркою характеристик, очікувань та асоціацій, які виникають у споживача товару. Згідно з визначенням будь-який бренд $\epsilon$ торговою маркою, але не кожна торгова марка може стати брендом.

Слід зауважити, що бренд — це торгова марка міжнародного рівня, яка здобула світове визнання й підтвердила свою репутацію (доволі відома споживачам, суспільству та популярна у населення).

Отже, кожна товарна марка намагається обернутися на бренд і стати відомою у всьому світі.

Процес формування бренду містить такі етапи:

- позиціювання бренду;

- формування стратегії бренду;

- розроблення ідеї бренду;

\footnotetext{
${ }^{1}$ Рожков И. Я., Кисмерешкин В. Г. Указ. соч.

2 Ілляшенко С. М. Зазнач. твір.

${ }^{3}$ Кардаш В. Я. Зазнач. твір.
} 
- пошук імені бренду;

- $\quad$ тестування бренду ${ }^{1}$.

Отже, щоб здобути статус бренду, товарна марка повинна стати популярною на ринку та здобути довіру покупців. Особливу цінність брендові надає престижність товару, яка залежить від багатьох факторів - таких, як особливості країни, місцевості, галузі, де товар вироблено, та авторитету фірми виробника. Так, наприклад, Франція відома своєю високою модою, Швейцарія - точністю, Німеччина - добротністю. Бургундські вина, шотландське віскі, швейцарські сири купують передусім тому, що їх вироблено в цих регіонах і їхня висока якість поза сумнівом.

Отже, основна вимога, якій має відповідати маркована продукція, полягає в незмінності іï якості, тому що саме на цьому базується прихильність споживача до конкретної марки продукту, яка здобула світове ім'я і стала брендом.

Враховуючи викладене вище про стратегію створення власного імені виробника, значення маркування товару та підкреслюючи свою оригінальність і якість на світовому ринку,- усі ці критерії мають відповідати оригіналові.

Виникає питання: як відрізнити (ідентифікувати) товари однієї групи 3 однаковим маркуванням - чи належить певний товар до оригінальної продукції, чи є ліцензійною копією або підробкою?

Процедуру ідентифікації проводять для виявлення тотожності невідомого об'єкта відомому на основі співпадіння ознак. Ідентифікація (від лат. identifico — ототожнення) — ототожнювання об'єктів, розпізнавання, визначення відповідності розпізнаваного об’єкта своєму образу (знаку).

Отже, ідентифікація товарів — це процес виявлення відповідності досліджуваних товарів (об’єктів) аналогам (базовим моделям, зразкам) з однорідної групи, яка характеризується сукупністю технологічних показників або описом товарів на маркуванні на основі характерних ідентифікаційних ознак. Водночас засобами ідентифікації товарів $є$ нормативні й технічні документи (стандарти, ТУ та ін.), які регламентують показники якості, а також товарно-супровідні документи (накладні, сертифікати, якісні посвідчення, що відображають інформацію про товар для непродовольчої групи товарів: назву товару, марку, модель, артикул тощо).

Одним із простих методів ідентифікації є органолептичний метод. За допомогою цього методу визначають співвідношення показників відповідності товару за визначеними критеріями на основі аналізу сприйняття органів чуття людини. Під час ідентифікації товару можна визначити такі показники: зовнішній вигляд, форму, колір, блиск, прозорість, консистенцію, щільність, еластичність, запах, аромат, букет, соковитість, ніжність тощо.

Слід зазначити, що перевагою органолептичного методу є його доступність і простота, а недоліком - недостатня достовірність. Тому

${ }^{1}$ Гаркавенко С. С. Зазнач. твір. 
органолептика не може бути єдиним критерієм ідентифікації, а для більшої ймовірності й об'єктивності слід послуговуватися іншими методами - залежно від засобів вимірювання, які, зі свого боку, поділяють на фізичні, хімічні, фізико-хімічні та мікробіологічні.

Ідентифікація зазвичай потребує багатопланових досліджень як досвідченими фахівцями - товарознавцями, так і висококваліфікованими науковцями - експертами ${ }^{1}$.

Отже, для того щоб з'ясувати, що таке підробка і що таке копія, та за якими критеріями визначати, до якої категорії належить товар, потрібен комплексний підхід з урахуванням вивчення наявного маркування та фактичного товарного стану.

Підробкою варто вважати будь-який товар, на якому стоїть марка виробника, який жодного відношення до цієї речі не має. Простіше кажучи, якщо на сумці є логотип Louis Vuitton, а на ярлику зображено емблему невідомого турецького заводу виробника, то це, найшвидше, $є$ підробкою ( fake).

Крім того, іноді підробку можна виявити за органолептичними показниками, а саме - порівнюючи за допомогою органів чуття характеристики основних споживчих властивостей і зовнішній вигляд (форму, матеріал виробу, кольорову гаму, акуратність і точність нанесення декорованих вставок чи, навпаки, їхню відсутність, наявність яскраво вираженого запаху фарби, що не $є$ характерним для оригіналу тощо).

Варто зауважити, що цінова пропозиція також має важливе значення: так, вартість підроблених товарів під іменем відомих марок $є$ значно нижчою за вартість справжніх товарів цих марок (наприклад, сукня відомого бренду Gucci не може коштувати \$20-30: це свідчить про те, що такий товар є підробкою).

Деякі відомі бренди щосили прагнуть максимально захистити свою продукцію від підробок, тому постійно поліпшують захист продукції різноманітними нововведеннями (наприклад, голограмами, запровадженням новітніх технологічних процесів та інших засобів захисту). Висока якість продукції $є$ головним захистом, адже не кожний здатен повторити весь технологічний процес виробництва, однак, зустрічаються винятки. Сьогодні підробляють абсолютно все - від одягу до аксесуарів і туалетної води та інших товарів.

Найчастіше підробку поставляють з Китаю, Індонезії, Туреччини й інших країн Східної Свропи та Східної Азії. Однак, це зовсім не означає, що країна прямо вказує на підробку, тому що більшість виробників переносять туди свої виробництва через низькі податки й дешеву робочу силу, що в остаточному підсумку значно здешевлює виробництво взуття й одягу.

Права власності на знаки для товарів і послуг реалізують у двох напрямах - усередині країни й у міжнародному масштабі. Більшість країн

\footnotetext{
${ }^{1}$ Малигіна В. Д., Титаренко Л. Д. Зазнач. твір.
} 
запровадили систему реєстрації та охорони торгових марок як іноземних, так і власних виробників.

Маємо зазначити, що у міжнародній практиці зареєстрований торговий знак позначають літерою $R$ у колі. Реєстрація торгових знаків є добровільною, оскільки потребує значних витрат.

До системи реєстрації та охорони торгових марок усередині країни належать: Україна, Франція, Італія, Австрія, Швеція, Іспанія, Португалія, Греція, Туреччина, Росія, латиноамериканські країни, де діє принции реєстраціï, тобто для охорони торгової марки потрібен сам факт реєстрації знака в патентному відомстві, що й забезпечує охорону (пріоритет реєстраціï) ${ }^{1}$.

В Україні державну реєстрацію товарних знаків здійснює Держпатент України на підставі Закону про ОПЗТП 2.

Так, в Україні відповідно до ст. 5 згаданого Закону право власності на знак засвідчують свідоцтвом, видача якого означає, що знак є зареєстрованим. Свідоцтво надає його власникові виняткове право користуватися й розпоряджатися знаком на власний розсуд, забороняти іншим особам використовувати зареєстрований знак без дозволу власника, за винятком тих випадків, коли використання знака не визнано законодавством порушенням прав власника свідоцтва.

Строк дії свідоцтва становить 10 років від дати подання заявки до Національного органу інтелектуальної власності (далі - HOIB) та продовжується НОIВ за клопотанням власника свідоцтва щоразу на 10 років (за умови сплати збору в порядку, визначеному п. 2 ст. 18 цього Закону). Порядок пролонгування строку дії свідоцтва визначає центральний орган виконавчої влади, що забезпечує формування державної політики у сфері інтелектуальної власності. Відповідно до п. 5 ст. 16 Закону про ОПЗТП свідоцтво надає його власникові виняткове право забороняти іншим особам використовувати без його згоди, якщо інше не передбачено цим Законом ${ }^{3}$.

Згідно зі ст. 229 КК України предметом злочину є незаконне використання знака для товарів і послуг, фірмового найменування, кваліфікованого зазначення походження товару або інше умисне порушення права на ці об’єкти, якщо це завдало матеріальної шкоди у значному розмір ${ }^{4}$.

Крім того, варто зауважити, що відповідно до ст. 16 Закону про ОПЗТП власник свідоцтва має право дати будь-якій особі дозвіл (видати ліцензію) на використання знака на підставі ліцензійного договору. Ліцензійний договір повинен містити умову про те, що якість товарів і послуг, виготовлених

\footnotetext{
${ }^{1}$ Дідківський М. І. Зазнач. твір.

${ }^{2}$ Про охорону прав на знаки для товарів і послуг: ... . URL: https://zakon.rada. gov.ua/laws/show/3689-12 (дата звернення: 04.06.2020).

${ }^{3}$ Там само.

${ }^{4}$ Кримінальний кодекс України: ... . URL: https://zakon.rada.gov.ua/laws/ show/2341-14 (дата звернення: 04.06.2020).
} 
чи наданих за ліцензійним договором, не буде нижчою за якість товарів і послуг власника свідоцтва і що останній здійснюватиме контроль за виконанням цієї умови ${ }^{1}$.

Сьогодні багато охочих придбати одяг відомих брендів, але фінансові можливості в усіх різні, тому сучасні кутюр' $є$ активно випускають за ліцензійним договором одяг під іменем відомого бренду — так звану копію. Країна-замовник ретельно стежить за тим, щоб манера та почерк майстра в цьому разі залишалися незмінними - так само, як стиль і образ бренду. Вибір виконавця залежить від можливостей конкретної фабрики, адже необхідно, щоб там відбувалося масове виробництво якісного одягу, взуття й аксесуарів. Зазвичай виробником других ліній відомих брендів є Китай.

Для того щоб ціна виробів була демократичною, використовують тканини з більш простим складом, а технологію виробництва цілком автоматизують. Представники бренду контролюють виробничий процес на території країни-виконавця й відповідають за кожен виріб. Крім того, замовник зобов'язаний забезпечити фабрику своїми кресленнями, викрійками та лекалами, висунути чіткі вимоги до оброблення, лейблів, забезпечити відповідною фурнітурою (гудзиками, кнопками, застібками-блискавками та ін.) і навіть майбутнім пакуванням. Завдяки всім цим заходам можна розраховувати на придбання за доступною ціною якісної продукції, виконаної відповідно до вимог відомого бренду.

В Україні не можуть бути зареєстровані як товарні знаки позначення, які $є$ тотожними або схожими настільки, що їх можна сплутати з чужими знаками для однорідних товарів чи послуг або фірмовими найменуваннями, які відомі в Україні й належать іншим особам (наприклад, Soni Ericssyn замість Sony Ericsson, Panasonix замість Panasonic, Smirnov замість Smirnoff та ін.) ${ }^{2}$. Власник свідоцтва має право вимагати їх усунення з товарів і пакування з огляду на ст. 229 КК України, відповідно до якої караються «незаконне використання знака для товарів і послуг, фірмового найменування, кваліфікованого зазначення походження товару або інше умисне порушення права на ці об'єкти, якщо це завдало матеріальної шкоди у значному розмірі» ${ }^{3}$.

Висновки. Виходячи з викладеного вище, слід зазначити, що торгова марка не тільки підкреслює індивідуальність виробника, а є унікальним об'єктом інтелектуальної власності. Для того щоб уникнути незаконного копіювання відомих торговельних марок, потрібно реєструвати їх відповідно до чинного законодавства. Отже, реєстрація торгової

${ }^{1}$ Про охорону прав на знаки для товарів і послуг: ... . URL: https://zakon.rada. gov.ua/laws/show/3689-12 (дата звернення: 04.06.2020).

2 Дідківський М. І. Зазнач. твір.

${ }^{3}$ Кримінальний кодекс України: ... . . URL: https://zakon.rada.gov.ua/laws/ show/2341-14 (дата звернення: 04.06.2020). 
марки є запобіжним та охоронним заходом, спрямованим на запобігання порушенню прав власника.

Сучасна нормативно-правова база, яка регулює захист торговельних марок як об'єктів інтелектуальної власності в Україні, загалом відповідає міжнародним стандартам, проте, зважаючи на наявність на ринку неякісної продукції та підробок, потребує вдосконалення.

\section{Referenses}

Didkivskyi, M. I. (2006). Zovnishnoekonomichna diialnist pidpryiemstva: navch. posib. Kyiv. [in Ukrainian].

Harkavenko, S. S. (2002). Marketynh: pidruchnyk. Kyiv. [in Ukrainian].

Illiashenko, S. M. (2005). Marketynhova tovarna polityka: pidruchnyk. [in Ukrainian]. Kardash, V. Ya. (2000). Marketynhova tovarna polityka: navch.-metod. posib. Kyiv. [in Ukrainian].

Kryminalnyi kodeks Ukrainy: Zakon Ukrainy vid 05.04.2001 r. № 2341-III (zi zmin. ta dopov.). URL: https://zakon.rada.gov.ua/laws/show/2341-14 (data zvernennia: 04.06.2020). [in Ukrainian].

Malyhina, V. D., Tytarenko, L. D. (2009). Osnovy ekspertyzy prodovolchykh tovariv: navch. posib. [in Ukrainian].

Pro okhoronu prav na znaky dlia tovariv i posluh: Zakon Ukrainy vid 15.12.1993 r. № 3689-XII (zi zmin. ta dopov.). URL: https://zakon.rada.gov.ua/laws/ show/3689-12 (data zvernennia: 04.06.2020). [in Ukrainian].

Rozhkov, I. Ia., Kismereshkin, V. G. Brending. (2019). Ucheb. dlia bak-v. Moscow. [in Russian].

\section{И. И. Бордакова \\ ИСПОЛЬЗОВАНИЕ ТОВАРНЫХ ЗНАКОВ (ТОРГОВЫХ МАРОК) И ИХ ЗНАЧЕНИЕ}

В статье проанализировань основнье этапь формирования собственного имени, стиля, образа производителя. Одним из основных критериев товара и важнейтим источником информации о продукции (товаре) на рынке является наличие маркировочных обозначений (фирменного имени, знака, образа, стиля и т. д.). Наличие элементов маркировки индивидуализирует товары и услуги. Под товарнымм знаком понимают марку или её часть, защищённую юридически, что даёт продавиу исключительное право использовать марочное имя или марочный знак.

Безусловно, использование товарного знака является своеобразным звеном между производителем и потребителем, служит активным средством привлечения внимания покупателей к продукту и позволяет потребителям выбрать необходимые им товары определённого производителя.

Следует отметить, что одним из средств идентификации товара является маркировка. Маркировка товаров считается неотъемлемой частью товара. Она обеспечивает потребителей актуальной информацүией о соответствуюшем товаре, таре и упаковке, а также отражает качество и безопасность продукции. В условиях рыночной экономики существенно возрастает значение товарных знаков - брендов, для 
распознавания одинаковых товаров, выпускаемых различными производителями, поскольку товары, представленные на потребительском рынке различными производителями, всегда отличаются характеристиками, признаками, качеством и т. п., а товарный знак (бренд) - это знак, помогающий отличить продукт (товар) одного производителя от такой же продукиии другого производителя.

На современном международном рынке отмечается всё возрастающая роль торговых марок и знаков, что ставит производителя перед необходимостью регистрировать свои торговые марки, которые, в свою очередь, становятся объектами интеллектуальной собственности. Однако, создать престижную марку международного масштаба под силу только крупным товаропроизводителям, способным выпускать качественные товары, поставляемые на различные рынки, и вкладывать значительные средства в их продвижение. Соответственно, правообладатели товарных знаков стремятся защчитить свою продукцию от подделки, индивидуализировать её и циивлизованно продвигать на потребительском рынке. Но желающих заработать на имени известного бренда очень много, поэтому появляются подделки, что вредит репутации производителя бренда. Эта проблема связана с большим количеством подделок, незаконно ввезённых на территорию Украинь без товарно-сопроводительных документов и реализуемых в магазинах и на рынках.

Таким образом, для того чтобь избежать незаконного копирования известных торговых марок, требуется их регистрация в соответствии с действуюшим законодательством.

Следовательно, регистрация торговой марки является мерой и охранным мероприятием, направленным на предупреждение нарушения прав собственника. Современная нормативно-правовая база, регулирующая зашииту торговых марок как объектов интеллектуальной собственности в Украине, в иелом соответствует международным стандартам, но (учитыввая присутствие на рынке подделок) нуждается в совершенствовании.

Ключевые слова: маркировка, товарный знак, торговая марка, торговое наименование, фирменньій стиль, бренд, идентификация, подделка, копия, качество, право собственности, интеллектуальная собственность.

\section{Bordakova \\ THE USE OF TRADEMARKS (TRADE NAMES) AND THEIR SIGNIFICANCE}

The main stages of formation of own name, style, image of the manufacturer of own products were analyzed in this article. One of the main criteria of a product and the most important source of information about products (goods) at the market is presence of marking (brand name, sign, image, style, etc.). Presence of label elements makes up individualization of goods and services. The term 'trademark' refers to a trade-mark or its juridically protected part that gives a shop assistant the exclusive right to use a brand name or a brand mark. 
There is no doubt that the use of a trademark is a kind of link between manufacturers and consumers, an effective method for attracting customers attention to the product allowing consumers to choose appropriate products of a particular manufacturer.

It should be noted that one of the means of identifying a product is marking. Marking is considered to be an integral part of goods. It provides consumers with relevant information on a corresponding product, container and packaging. It also reflects quality and safety of products. Significance of trademarksbrands is increasing considerably in conditions of market-oriented economy for distinguishing the same goods produced by different manufacturers. Since goods introduced to consumer market by different manufacturers always differ by characteristics, features, qualities, etc. A trademark (brand) is a sign that helps to distinguish a product of one manufacturer from the same product of another.

The growing role of brands and trademarks is stressed in today international market. Thus, a manufacturer is in front of the choice of registration of trademarks which in turn become objects of intellectual property. However, creating an exclusive international scale brand is only possible for large commodity producers who are able to produce quality goods delivered to different markets and invest enormously into their promotion. Accordingly, trademark holders aim to protect their products from counterfeiting, individualize them and promote at the consumer market in a civilized way. But there are many people who want to make money using a name of a famous brand, therefore, counterfeiting that spoils reputation of a brand manufacturer appears. This problem is connected with a large number of counterfeiting illegally imported into the territory of Ukraine without commodity accompanying documents, and then sold in stores and markets.

Thus, known trademarks are required to be registered in accordance with the current legislation in order to avoid cases of illegal copying.

To conclude, registration of a trademark is a preventive and protective measure aimed at preventing violations of the rights of an owner. The modern regulatory framework regulating protection of trademarks as objects of intellectual property in Ukraine, in general, complies with international standards, but needs to be further improved taking into consideration counterfeiting at the market.

Keywords: marking, trademark, trade names, style, brand, fake, intellectual property.

Надійшла до редколегії 14.07.2020

Бордакова I. I. Використання товарних знаків (торгових марок) та їх значення. Теорія та практика судової експертизи і криміналістики : зб. наук. пр. / редкол.: О. М. Клюєв, В. Ю. Шепітько та ін. Харків : Право, 2020. Вип. 22. C. 527-537. DOI: https://doi.org/10.32353/khrife.2.2020.42. 